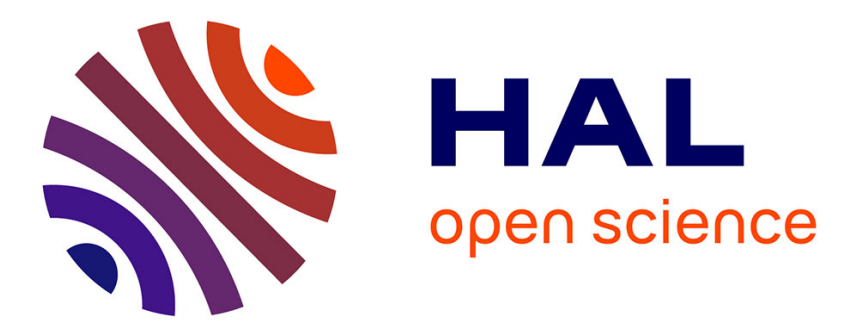

\title{
Conceptualizing Learning from the Everyday Activities of Digital Kids
}

\author{
Justin Dillon
}

\section{To cite this version:}

Justin Dillon. Conceptualizing Learning from the Everyday Activities of Digital Kids. International Journal of Science Education, 2007, 29 (12), pp.1509-1529. 10.1080/09500690701494076 . hal00513352

\section{HAL Id: hal-00513352 \\ https://hal.science/hal-00513352}

Submitted on 1 Sep 2010

HAL is a multi-disciplinary open access archive for the deposit and dissemination of scientific research documents, whether they are published or not. The documents may come from teaching and research institutions in France or abroad, or from public or private research centers.
L'archive ouverte pluridisciplinaire HAL, est destinée au dépôt et à la diffusion de documents scientifiques de niveau recherche, publiés ou non, émanant des établissements d'enseignement et de recherche français ou étrangers, des laboratoires publics ou privés. 


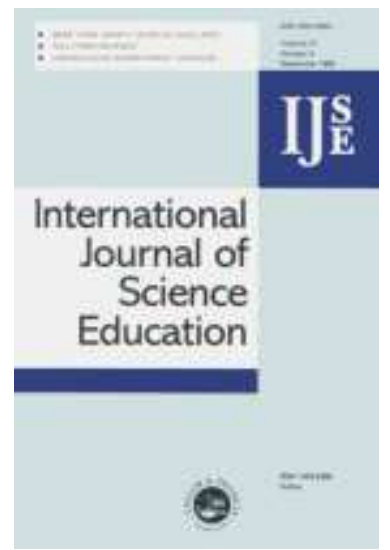

\section{Conceptualizing Learning from the Everyday Activities of Digital Kids}

\begin{tabular}{|r|l|}
\hline Journal: & International Journal of Science Education \\
\hline Manuscript ID: & TSED-2007-0177 \\
\hline Manuscript Type: & Special Issue Research Paper \\
\hline Keywords: & informal education \\
\hline Keywords (user): & \\
\hline \multicolumn{2}{|l}{} \\
\hline
\end{tabular}

\section{S ScholaroNE" \\ Manuscript Central}




\title{
Conceptualizing Learning from the Everyday Activities of Digital Kids
}

\author{
Sherry Hsi \\ University of California Santa Cruz, USA
}

\begin{abstract}
This paper illustrates the intensified engagement that youth are having with digital technologies and introduces a framework for examining digital fluency - the competencies, new representational practises, design sensibilities, ownership, and strategic expertise that a learner gains or demonstrates by using digital tools to gather, design, evaluate, critique, synthesize, and develop digital media artifacts, communication messages, or other electronic expressions. A primary goal of this paper is to identify promising perspectives through which learning is conceptualized, and to share the methodological challenges in investigating digital fluency in both individual and collaborative learning activities that take place in complex naturalistic settings and socially-constructed online worlds. A review is provided of the current and prospective research methods that researchers use to capture, document and study the compelling ways in which children and young people are using digital technologies such as Information and Communication Technologies (ICTs), social networking software, video games, multimedia authoring tools, and mobile phones in everyday life to learn and play. The paper argues for a need to study the authentic, inventive, and emergent uses of digital technologies and interactive learning environments among youth to contribute to advancement of theories of everyday learning and to build a deeper understanding of how learning occurs in out-of-school settings from a practise-oriented perspective rather than
\end{abstract} p. 1 
a knowledge-centred one. Implications for instructional practise are also discussed in addition to ethical and pragmatic issues that will need to be addressed in the study of digital kids.

\section{Introduction - Vignette of a Digital Kid}

This vignette ${ }^{1}$ featuring a twelve-year old boy and thirteen-year old girl is provided so the reader can gain common footing to illustrate the intensified engagement that takes place between youth, digital technologies, and online environments, as well to demonstrate the complexity of activities and relationships involved in conceptualizing learning in out-ofschool learning contexts.

James is a twelve-year old boy who first learned how to use a personal desktop computer when he was two years old. Having grown up with a home computer with multimedia story book CD-ROMs designed for early literacy and other commercially available educational software (e.g., Reader Rabbit ${ }^{\mathrm{TM}}$, KidPix ${ }^{\mathrm{TM}}$, Oregon Trail ${ }^{\mathrm{TM}}$ ), James is familiar with different genres of digital-based experiences: adventure games, drawing tools, information search, and online reading. James is an example of a digital kid, an avid consumer of traditional media, electronic games, and web-based information (Oblinger, 2003). When James was ten years old, multi-user web sites such as Whyville (www.whyville.net) and Neopets (www.neopets.com) were available on the Internet for children. These play-based activity spaces allowed children to play online games, text chat with other children, win virtual tokens, and purchase virtual prizes depicted as

\footnotetext{
${ }^{1}$ This vignette is based on direct observations made by the researcher of youth in homes, museums, and conversations with parents of digital youth.
}

p. 2 
everyday objects - face parts, pet food, snacks, or clothing (Foley \& Kobaissi, 2006). In these online spaces, text messages are exchanged with other online participants who happen to be in the space at the same time, and virtual objects can be traded with other community members. James is no stranger to authoring online content. Using the built-in web editor in Neopets, James learned how to create basic web pages and customize the appearance of the online environment. He regularly looks for songs on the Internet and downloads them so he can listen to them while doing other online activities. Outside of school, if no parental restrictions or limits are placed on time, James uses the computer before and after school to play online games and chat with friends during the game playing. His daily routine involves checking electronic mail on 'MyYahoo', playing online adventure conquest games, chatting with friends via text messages, printing out typed homework assignments, and emailing his assignment to his teachers. His mobile phone is used as an appliance to help him accomplish daily tasks - finding out what time it is, looking up bus schedules, and calling parents and friends to arrange meetings and transportation around town. He also uses his mobile phone for entertainment, playing games, taking photos, and sending to and receiving messages from his school friends. He made the mistake of giving his mobile phone number to a girl at school who now sends him text messages over five times a day, sometimes during school hours. James is not unlike other young people in the UK and in Japan that use an embedded digital camera on a mobile phone to annotate a photo they have taken, communicate via text messaging to show their physical location, socialize, and make plans to meet friends (Kindberg, Spasojevic, Fleck, \& Sellen, 2004; Ito, 2004). New media tools enable James to create a broad range of personal expression and to share these digital expressions with a wider 
audience, who in turn, take his original ideas and work, and create shared expressions in a variety of new and unexpected ways.

Being in the US, James gains access to the Internet via a computer at school, in the public library, and via a shared family computer at home. Like the other $44 \%$ of teens in the US (Lenhart \& Madden, 2005; Lenhart, Madden, \& Hitlin, 2005), James owns multiple personal media devices including a mobile phone and a Nintendo Gameboy ${ }^{\mathrm{TM}}$. Both devices have games and ways to communicate wirelessly via text messaging with other players. His preferred activities include simultaneously watching television while browsing the internet from a home desktop computer to stay connected with online friends and research personally-meaningful information such as clues to adventure games, strategies to game play, or to review popular songs (e.g., MP3s) available for online purchase.

James' friend, Sarah is 13 , and also spends time playing online games on her family's home computer, but she prefers to spend more of her leisure time socializing with her school friends via text messaging and building her web profile in MySpace.com, an online social networking space, in which Sarah can create an online identity and describe her likes and dislikes for certain music, foods, as well as describe of how she would like others to perceive her online. These features are typical of online social identity spaces (Donath \& Boyd, 2004.) Her web profile featured in the software also allows Sarah to publish her favorite website links and post them as a collection of bookmarks that reflect her interests and preferences, providing another way for others to view her online identity and learn about her interests. Her daily routine involves logging into an email programme 
immediately upon coming home after school and chatting with friends online to stay connected with her circle of school friends. While she uses Internet tools such as an online translation programme to complete her Spanish homework, Sarah's primary use of the Internet is to have informal conversations with her peers.

Both James and Sarah choose to spend their time in recreational online activity spaces. James and Sarah are typical of most digital kids that use digital technologies for leisure to play games (Gee, 2003). They have mastered the technical and online colloquial vernaculars such as 'side-scrolling', 'faqs', 'brb', 'ttyl', 'AFAIK', 'cheats', and 'mods' are used in their everyday language. One massive multi-user role-playing game that Sarah and Jamie enjoy is one where they can select a job from a list of professions (e.g., cross bowman, cleric, blacksmith, etc.) and see how well they can make a living in an online virtual village. Players are rated on attributes such as strength, dexterity, fame, intelligence, and luck in the online community by other online players. Progress in the game is based upon accumulating virtual tokens, experiences gain while accomplishing specific job-related tasks, as well as receiving performance ratings by other players in a complex system of reputation-building, decision-making, and resource management that characterize the game. Feedback on and assessment of Sarah's and James' performance in the game, given by the game system as well as other online players that mentor their progress, is immediate and relevant to the task they are carrying out, and the outcomes allow players to make informed decisions about the next level to achieve.

James and Sarah both represent a new generation of children and young people sometimes called "millennials" that have grown up in a digital, electronic, and 'wired' 
world since the invention and spread of the Internet and the World Wide Web, (Murray, 1997), and the growing ubiquity of wireless mobile networks (Brown, 2000). They not only use digital tools as part of their everyday routine activities to support communication, school assignments, way finding around town, and play, but also use ICTs, multimedia software, and authoring tools to rapidly create and exchange personally-meaningful messages, custom tools, and digital media artifacts across distributed social networks and online communities (Cheskin, 2004). In 2002, more than $78 \%$ of children between the ages of 12 and 17 were online in the US, growing to $87 \%$ in 2005 (Lenhart, Madden, \& Hitlin, 2005). In the UK, 41\% go online on a daily basis (Livingstone \& Magdalena, 2004) and 90\% of young adults own mobile phones (Crabtree, Nathan, \& Roberts, 2003). According to van Schie and Wiegman (1997) an average of seventy percent of Dutch children in the $7^{\text {th }}$ and $8^{\text {th }}$ grades had played electronic video games out-of-school in a given week (75\% boys, $63 \%$ girls) and comparable results were found throughout Europe and North America (Goldstein, 1994). As early as $2001,95 \%$ of the 15-24 year olds in Japan owned web-enabled mobile phones (Thorton \& Houser, 1994). While Internet and online media use are more commonly documented and researched during school hours and in formal settings, one would expect even more use to occur outside of school hours among children in the middle class given that children have more free time and opportunities for technology access through libraries, homes of friends, and Internet cafes.

Popular books titled 'Don't worry mom, I'm learning!' and 'Everything Bad Is Good for You: How Today's Popular Culture Is Actually Making Us Smarter' argue in favor of

p. 6 
technology-based interest-driven activities and play with technology, especially digitalbased video games, because they benefit development and learning (Prensky, 2006; Johnson, 2005). Yet, a large societal concern exists among adults including parents, school administrators, education policy makers, and teachers alike that this engagement with and attraction to media and digital-based ways of playing are actually interfering with children's development, health, and schooling, influencing social behaviour, and consequently distracting youth's attention away from learning new content, participating in civically-minded activities, and acquiring future workplace skills. The possibilities of Internet addictions, gambling, cyber bullying, online thefts, and exposure to pornography, are some of the many risks posed by engaging in networked digital technologies (BBC Online, 2006; Children's Partnership, 2005; Kaiser Family Foundation, 2005; Keith \& Martin, 2005; Thornburgh \& Lin, 2002). Teachers have also reported that participation in online activities such as games and online chat communities promote and further unwelcomed student behaviours, such as distraction from school assignments, disenfranchisement from society, and other problems that plague youth's development. Within the noise of conflicting opinions, how do citizens, especially educators, make sense of the role and use of digital technologies in the lives of youth?

With the demands for greater accountability, evidence-based research, and data-driven decision making in education, what research and usable knowledge is available to education practitioners and the public that demonstrates the value of learning that involve digital-mediated environments in out-of-school settings? To date, there has been no systematic longitudinal study of kids' cumulative experience with digital media from 
childhood to adulthood, nor understanding of the cumulative effects of digital media upon cognition, learning, and development (Lyman et al., 2005). Given that future scientists and engineers will likely come from this current and future generation of digital kids who are spending more time out-of-school engaged in online play, it will be important to understand the impact and relationship between digital play, formal learning, and science education generally. Moreover, the study of the everyday activities of digital kids has the potential to contribute to the advancement of theories of everyday learning and to build a deeper understanding of how learning occurs in out-of-school settings

\section{Framing Everyday Activity as Digital Fluency}

Using a frame of digital fluency, one can begin to describe the new practises that a learner gains or demonstrates by using digital tools to gather, design, evaluate, critique, own, synthesize, and develop digital media artifacts, communication messages, or other electronic expressions. This is not to be confused with computer literacy or definitions of technological fluency that are typically associated with mastering computer productivity skills, manipulation of electronic data and applications, and assessment of those skills for workforce preparation purposes. This extends prior information technology fluency frameworks (i.e., access, manage, integrate, evaluate, critique, create, communicate, assess) to frame fluency as constructing new representational practises, design sensibilities, ownership, and strategic expertise gained, taking a practise-oriented perspective rather than a data, information, or knowledge-centred perspective. While digital kids may be learning disciplinary content during their play, this is not their main goal when engaged in these activities. A digital fluency framework recognizes that learning is voluntary participation in a complex and distributed system of people, 
settings, objects, and interactions, but given the electronic medium, differs from standard conceptualizations of an activity system in important ways. Digitally fluent youth demonstrate and become more expert in the following practises:

- Digital kids build on their own skills and knowledge, and that of other participants, enabling them to reason from their own experience and create new ones. In the case of James and Sarah, what they learn, in part, is gleaned from their peers and available online information.

- Digital kids take on different identities and multiple roles - James and Sarah choose different online representations of themselves in online profiles or as avatars and choose which information they want presented to others.

- Digital kids voluntarily spend time working on a set of technology-based skills and becoming fluent in them over time. James and Sarah do not always use computers to learn how to type using typing software programmes with the primary intent of learning how to use technology, but are immersed in games and activities that are meaningful and authentic to them, and require typing skills to accomplish their goals. With respect to settings, learning occurs not only in a physical context, but also in a virtual context that is dynamically created by the participants through continual interaction in the space. An ad hoc social network is formed with others that sometimes share a common goal or interest. The common ground of learning is continually shifting as actors move from one location to another, gain new resources, or enter new conversations.

- Digital kids are co-constructing a social reality and establishing norms for participation. Digital kids are concurrently developing online practises of 
multi-tasking, judging online information based on social reputation, comparing multiple online information sources, and trying out new online identities (Dede, 2005). These online practises are fluid and emergent given they are defined by the participants online. As part of this social reality, learners participate in transient online communities. The distributed members of the community are constantly changing - James and Sarah can be engaged in an online game with other online participants for several months, but yet easily abandon that community for another more engaging or popular one.

- Digital kids take ownership of media creations and online expression. Here, ownership has blurry boundaries because of the distributed nature of how electronic media is easily created and exchanged via the Internet. Digital kids often embrace remix culture to produce meaning through the creation of objects, messages, representations, and other online expressions based on the re-use of other electronic expressions.

- With respect to objects and representations, digital kids consume multimedia that was created by others and created by themselves, engaging in 'two-way literacies' in cultural production of knowledge (Ito, 2005). Digital media production tools and free web-based authoring tools are enabling youth to create multimedia stories, join online hobby communities, and create personally meaningful virtual objects in 3D online worlds, using not only text, but images, video, and other media. The digital objects created are dynamically changing in their representations as they are created and changed by online learners. 
- Digital kids demonstrate fluency by simultaneously operating and managing multiple devices and multiple media types including cell phones, the Internet, and television. This multi-tasking behaviour and attention switching is common.

- Digital kids work on complex problems that require distributed teams to solve. In the video games that James plays, he engages resources and expertise provided by other online players as well as develops new game strategies.

\begin{abstract}
This beginning framework for digital fluency can help organize the contemporary practises of digital kids to systematically study the design and affordances of activity spaces to support digital youth experiences, meaningful play, and youth development.
\end{abstract}

\title{
Theoretical Perspectives on Studying Digital Kids
}

To study digital fluency among youth, various approaches and theoretical frameworks can be used, drawn from decade long developments in science education, developmental psychology, anthropology, and social cultural studies. These frameworks range from examining individual development of cognition and intellectual capacities (NRC, 1999), literacy, language development, skill acquisition, and disciplinary content learning to examining interpersonal relationships, whole activity systems, and situated communities of practise.

\footnotetext{
While researchers from different disciplinary traditions are conceptualizing learning from multiple perspectives, the framing of learning by digital kids' learning from a social cultural and play perspective appears to offer a promising approach.
}

p. 11 


\section{Play in New Cultural Worlds}

One perspective is to conceptualize the actions of digital kids as a form of play, examining the characteristics and types of play that is self-initiated, inventive, and spontaneous (cf. Hutt, 1973; Hyder, 2004) and the agency, intentionality, and seriousness with which young adults take on play-like activity or 'deep play' (Geertz, 1973). Extensive studies have been conducted on children at play and the ways that play contributes to cognitive, language, and social development that can be applied to the study of online environments. For example, digital kids are developing competencies in goal-oriented tasks such as those required of online games or simulations, and appear to learn and practise decision-making and important life skills. Prior research on child development, language development, and the prevailing social practises that children engage in as they participate in the formation of new cultural worlds and systems of activity (Corsaro, 2003; Nespor, 1997; Kyratzis, 2004) could also contribute to understanding youth development in digital learning environments. This perspective specifically helps us understand the cultural worlds and practises that children and youth constitute and manage for their own purposes. The aforementioned 'play' image is consonant with this image of technology-mediated, self-constituted culture. It is an alternative to some views of technological fluency that presume that youth should only or primarily are socialized into the established technological practises of adults (e.g., skills associated with workplace competence). An increasing number of studies help confirm the perspective that new technologies serve an important developmental function in the formation of youth microcultures (e.g., specialized online communities (Egan, 2000)) or 
practises in using mobile phones (Ito, 2004; Kasesniemi \& Rautiainen, 2002) that first and foremost serve the interests and needs of youth.

Part of play has also been associated with opportunities for role-playing and identity formation activities - the experience of exploring and trying on alternative identities and gender swapping (Turkle, 1999). With the open system architecture of new video games, personal expression, invention of new characters and adopting multiple identities (e.g., avatars, names, costumes, play objects, worlds) are possible. Because online environments collapse certain physical boundaries in which learning and interaction occur, one lens to view activity is from a cultural geographies perspective. This approach considers children's shifted negotiations of space and time (Green, 2002; Holloway \& Valentine, 2000). In cognitive studies of digital literacy, the specific representations that learners create including their annotations, interpretations, and the reasoning behind them can also be examined (c.f. DiSessa, 2000). The digital environment provides unique opportunities to capture the inscriptions, digital artifacts, and persistent representations created by youth and examine these over time.

\section{Socio-Cultural Views of Digital Fluency}

Given that many of these online and digital-based youth activities take place in collaborative spaces between peers and groups, socio-cultural views of learning that draw upon activity theory, situated learning, and theories of distributed cognition are useful and promising approaches for examining the social networking, game play, identity formation, and collaborative practises in communities that are central to conceptualizing learning and activity of digital kids. Socio-cultural approaches allow comparisons of 
learning activity between settings with levels of activity ranging from a micro-genetic level to the cultural influences of whole institutions (Engelström, 1996). Social cultural researchers are also studying the physical and human resources offered in a situated context and the access to these resources to better understand the interests and experiences of learners with different kinds of computing uses in an 'learning ecology' (Barron, 2004)

\section{Social networking}

Because social cultural perspectives emphasize examining cultural linguistics, language development, and discourse practises, researchers of digital kids study the conversations and social exchanges that takes place in online spaces such as online bulletin boards, text chat screens, online diaries such as 'blogs', as well as in the physical spaces and interactions among children in groups that gather around a screen, electronic media, or networked technologies. Learning is, thus, not seen as the acquisition of knowledge by individuals so much as a process of social inclusion, social participation, and engagement in the communication practises of a community. To understand a social network, researchers can examine who a learner considers a friend and the ways in which an individual becomes of legitimate member of a group or online community of practise (cf. Wenger), his or her intent participation in a community (Rogoff, 1996; 2003), how "repertoires of practise" form among them, and how language develops within a group of participants Guttierez, 2002). For example, the practise of argumentation as one form of discourse in a community of learners is being studied across multiple contexts of everyday science (Bell, Bricker, Lee, Reeve, \& Zimmerman, 2006). 


\section{Game play and games research}

The context of online games to study learning has recently been capturing the attention of researchers and educators. Because of their motivational hold on youth from compelling narratives, activity structure, scaffolding, dynamic feedback, high quality imagery, and collaborative nature, electronic game playing is seen as a possible venue for understanding how to create engaging learning environments and how to prescriptively design technology-mediated activity spaces and other games for education (see Barab, Warren, \& Ingram-Goble, 2006; Gee, 2003; Mitchell \& Savill-Smith, 2004). Digitallybased environments provide multi-generational spaces where dominant and nondominant groups together can gather to engage in participate in online learning communities, engage in collaborative problem solving, craft situated identities, and form new identity groups (Steinkuehler \& Chmiel, 2006). Researchers, social scientists, and philosophers of education are studying language, representations, and collaborations that take place in massively multiple player online role playing games (e.g., World War Craft, City of Villains, Civilization III), and in specific cases, designing online game environments for the purposes of study learning, discourse, and development (Gee, 2003; Squire and Jenkins, 2004) Game and literacy researchers like Gee find that well-designed video games support and embody important learning principles that can contribute to the design of other motivating learning environments (Gee, 2003). Games encourage the players to experiment with different ways of learning and thinking, necessarily situating learning in a social and cultural world. Online games are also effective learning environments in that they present complex problems to solve, often require collaboration to make progress, and provide scaffolding in the game design for active construction of

p. 15 
knowledge. Rather than focusing learning "content" in game or worrying about what kinds of content (good or bad) people are learning with video games, Gee argues that what they are doing is often good learning. The learning potential comes from the actions and decisions made by the player in a complex system of resources, social interactions, negotiations, and spatial navigation. Game expertise has been linked to the behaviours such as self-monitoring, problem-solving, principled decision-making, qualitative thinking, and superior short and long-term memory (VanDeventer \& White, 2002).

\section{Online Identity Development}

Youth can self-define their online personae or identities through different pictures, narratives, symbols, and other representations, as well as through their online interactions and behavoiurs. Most teens use different screen names and many pretend to be different people (Lenhart, Rainie, \& Lewis, 2001.) Identities can form through the creation of personal profiles listing friends, professional contacts, favorite websites, image collections, and other personally-meaningful digital information. Race, gender, and economic status which can be self-defined or made anonymous, no longer become important markers of status in a community, but instead other attributes are valued such as serving as a knowledgeable and accurate source of information, possessing a skill level in an online game, or having a reputation of being helpful amongst others in an online community. By examining the symbols, representational choices, and electronic discourse, one can gain insights into the identity formation and development of youth and their social relationships to others. To better understand the social phenomena of online identity creation, specialized interactive online environments have been created to 
specifically study the construction of online identities especially among youth in informal setting (Bers, 2001.)

Identity can be argued as an important lens for studying digital fluency. Because online identities are self-defined and constructed online through representations that user selected which can be different than their physical appearance, they often provide another way to examine how youth develop views of self, society, gender, and race.

\section{Methods and Tools for Studying Digital Kids}

Communications networks, whether organized by the mobile phone or the Internet, are changing the scale, national boundaries, institutional rules, scope and dynamics of kids' social worlds and activities. The notion of studying learning in a given setting will require expanding to include these virtual spaces and new geographies. Settings, interactions, social relationships, media messages, practises, and conversations made by digital kids are intertwined with digital media and digital technologies. If the activities of digital kids are conceived as new distributed systems of activity and the creation of new social cultural practises, methods used to study them will require innovative and progressive approaches that leverage multiple mixed-methods, computationally-based data collection tools, and comparative analyses. Table 1 provides a categorization of common and innovative methods being used to study digital youth: quiet capture, active elicitation, and cooperative inquiry. Quiet capture methods include both computationally-based and qualitative approaches to document the interactions of digital kids as they use online technologies. For example, web traffic software can be used to capture 'click stream' data: keystroke interactions, the duration of webpage visits, 
frequency of use, and the popularity of frequented websites by using "cookies", a piece of code that is downloaded to the user's machine and scripted to collect specific data. Clickstream data shows which keys were typed, which pages of a computer programme were visited and in what order, as well as how long the user remained at each page. Commercially available software installed on a youth's personal computer (e.g., SpectorSoftware, TypeRecorder ${ }^{\mathrm{TM}}$ ) can be configured to capture digital images of the whole computer screen every few seconds without interrupting the activity of the learner. Similarly, a computer-based tool called Morae ${ }^{\mathrm{TM}}$ can be used to continuously record a computer screen, while also capturing the facial expressions and utterances of the participant via digital video capture. New pen-based capture systems (e.g., Anoto Pen) used on regular paper to capture and record inscriptions are another approach (see Maldonado, Lee, \& Klemmer, 2006). Quiet capture approaches have the benefit of not interfering with the activity of the participant, but also require consent by the research participant, and can create issues related to data reduction and shared interpretations of practise.

A second category of methods, referred to as active elicitation shown in Table 1, involves the researcher conducting clinical interviews, structured tasks, and tests with youth users - normative practise in cognitive studies and science education research. The value in active elicitation is needed validation of quiet capture data methods, though because this typically takes place in controlled or lab settings, the research data can only speak indirectly to learning as it occurs in everyday settings. In addition to analysing the verbal talk of digital kids, their typed messages, user-created graphic annotations, and media

p. 18 
work products can be examined in the context of actions made in the online environment using tools like Progress Portfolio that allow learners to take digital snapshots of their computer screens (Loh, Radinsky, Reiser, Gomez, \& Edelson, 1997).

A final category of methods includes what can be referred to as "cooperative inquiry" approaches to research, which necessarily engages youth to voluntarily participate in the data collection about themselves and/or others. For example, design researchers at the Art Center in Pasadena interviewed eleven pairs of "tweens" between the ages of 10 and 12 asking youth to photograph events or objects that were of significance in their life which included their rooms, backpacks, friends, family, and daily activities (Art Center College of Design, 2004), (cf. Brenda Laurel.) The data that resulted was a mix between digital story telling and an online diary, providing insights into what was important in the lives of these kids. The use of diaries is another approach to gathering data about the conversations and activities of digital kids. Parents can participate as researchers by keeping diary reports to document the questions raised by their children in everyday activities (Callanan \& Oakes, 1992). Online diaries can be embedded in the flow of online activities to periodically prompt a participant to enter in learning moments or events that are meaningful to the participant (Vavoula, 2005).

Computer scientists from the human-computer interaction field have created 'technology probes', an online data collection tool in the form of an online 'pal, an avatar customizable by children (Druin, 2002; Hutchinson et al., 2003). By examining how the children choose to design their online avatar and what they tell their avatar during a play 
activity provides insights into the child's design process. These approaches outweigh active elicitation approaches, especially with younger children who have difficulty articulating their learning and rationale for activity (Van Kesteren, Bekker, Vermeeren \& Lloyd, 2003; Dix, 2003). In a similar approach one uses a video camera that sits near the participant. The participant is encouraged and coached to talk directly to the camera and the camera becomes an audience for the designs being produced (Lamberty \& Kolodner, 2005) Goldman-Segall has raised the issue of performing for the camera as a potential distraction (Goldman-Segall, 1999), but in this method, talking to the camera is encouraged and exploited as a feature. In a technique called Video Traces, research participants who are visitors in museums interact with an exhibit while being videotaped. After their interaction with the exhibit, visitors are asked to view the videotape of themselves and further elaborate and provide insights into their thoughts and actions (Stevens \& Hall, 1997). Other innovative tools have been developed such as DIVER which is used to understand not only individual activity, but whole activity systems and situated contexts using multiple, coordinated digital video camera capture, and digital video interaction analyses (Pea, 2006). The capture of whole contexts and practises through a 'guided noticing tool' can help focus on relevant activities in order to study activity in real-world spaces and leverage established interaction analyses methods (Pea, 2006; Jordan \& Henderson, 1995). Another form of data capture involves the use of embedded online assessments that are programmed to trigger a pop-up question at key points in an online game or simulation (Owston, Kushniruk, Ho, Pitts, \& Wideman, 2005). 
These cooperative inquiry research methods have the quality of allowing the participant to engage in research and design, and contribute to the collection and interpretation of data through their own activity and their own accounts. The advantages of engaging children as data collectors and curators of their own artifacts, knowledge, and insights is that data can be more easily collected in everyday settings, and carries the intentionality, authenticity, and perspective of the digital kids themselves.

Table 1: Overview of Methods used to Collect Data about Digital kids

\begin{tabular}{|c|c|c|}
\hline Category & Approaches & Sample tools \\
\hline Quiet Capture & $\begin{array}{l}\text { "Cookies" } \\
\text { Click streams (Log files) } \\
\text { Screen capture, inscription capture } \\
\text { Eye Tracking }\end{array}$ & $\begin{array}{l}\text { WebTrends } \\
\text { Spector Software } \\
\text { TypeRecorder } \\
\text { Morae }^{\mathrm{TM}} \\
\text { Anoto }^{\mathrm{TM}} \text {-based pens }\end{array}$ \\
\hline Active Elicitation & $\begin{array}{l}\text { Clinical interviews } \\
\text { Verbal protocols and Talk alouds } \\
\text { Sequestered tasks } \\
\text { Test performance } \\
\text { Design portfolios } \\
\text { Ethnographic interview }\end{array}$ & Progress Portfolio \\
\hline Cooperative inquiry & $\begin{array}{l}\text { Self- reports } \\
\text { Ethnography } \\
\text { Technology probes } \\
\text { Photo journal } \\
\text { Participatory design } \\
\text { Parent Diaries } \\
\text { Digital Video } \\
\text { Design informants } \\
\text { Portfolios }\end{array}$ & $\begin{array}{l}\text { Progress Portfolio } \\
\text { VideoTraces } \\
\text { DIVER } \\
\text { Virtual Usability Lab }\end{array}$ \\
\hline
\end{tabular}

p. 21 
Embedded online assessment

\section{Challenges and Barriers to Research on Digital Youth}

The study of everyday practises of digitally-mediated environments and digital kids presents rich opportunities to examine out-of-school learning and usable knowledge to help refine theories of learning and to help inform practitioners of the ways in which digitally-mediated technologies engage youth. However, because of the nature of activity that occurs largely out of the school classroom and/or out of formal institutional contexts, several challenges and barriers arise. Measuring educational progress is difficult because the goals for education are largely absent and/or there are no shared educational outcomes. A cultural tension continues to exist between institutional views of academic learning with the everyday learning that takes place among digital kids. Some promising work is being conducted to bridge the gap between kid's voluntary leisure activities and academic learning, examining closely the interactions of digital kids in online game play and the mapping of those interactions to standards of scientific literacy (Steinkuehler \& Chmiel, 2006).

As literature reviews have found, defining what constitutes learning from informal settings is both conceptually and politically complex (FutureLab, 2004). When the majority of practise and interactions occur in complex settings outside the school classroom, and also take place in extended virtual social worlds across multiple physical and online settings, what counts as learning and the assessment of educational progress

p. 22 
poses challenges for the researcher. More recently, multi-institutional and crossdisciplinary research initiatives and investments have been made to understand learning in informal settings and new systematic studies are being conducted to investigate learning that cuts across formal and informal learning contexts with a handful of studies that focus on digital cultures and fluency (Martin, 2004; CILS; NSF LIFE Centre; FutureLab). In addition, design-based learning sciences researchers are crafting play spaces that specifically leverage the features of informal play and gaming to support academic learning (Barab, Warren, \& Ingram-Goble, 2006).

Ideally, research should lead to sharable theories that can both advance an understanding of everyday learning and also communicate relevant implications to education practitioners, however, a fragmented view of digitally-mediated learning exists and the existing research based is far from coherent. Part of the fragmentation exists because of the differences in deep-seated beliefs about how to define educational progress that can reconcile classroom learning and schooling practises with everyday learning in digital play. In addition, researchers from different disciplinary traditions are often working at different levels of analyses and interaction, in some cases in absence of any learning or instructional theory, making it difficult to weave a coherent view that illuminates the role that digital learning is playing in youth's lives. Researchers studying digital kids come from fields that include communication and media studies, semiotics and literacy, information technology, psychology, anthropology, women studies, and library sciences to name a few. In constructing a learning framework to understand digital kids, there is also a limitation in viewing learning as simply communication or transmission of established knowledge from one peer to another, when children are concurrently 
inventing practises, tools, and online tool use in more short-lived time frames - youth practises are dynamic and shifting. Young people and children interact with media while on the go with web-enabled mobile phones, ubiquitous Internet access, and technology access in their learning landscape. Because learning is complex, mobile, and outside an institutional context, experimental conditions and methods are not easily achievable. Alternative approaches, like design-based research (DBR, 2004; Bell, 2004) offer a promising orientation towards examining emergent practises and engagement. With more collaboration across disciplinary boundaries as well as concerted efforts by researchers to make explicit those theories and practises that are foundational to their work, there is some hope to making more coherent the current pluralistic views of digital learning and play.

Research based on social cultural approaches will likely capture the complex features of this learning, but will require recognition that the context shifts in online environments, objects, and representations creating the need for innovative embedded computer-based methods and a willingness by learners to collect and interpret data through cooperative inquiry with researchers. A risk in specifically creating environments to support learning are the epistemological beliefs held by digital kids that educationally-designed software has an agenda which is not their own and thus presents a barrier to authentic use. Reconciling the social priorities of youth with school culture and teaching agendas may be difficult to achieve. Moreover, conceptualization of learning is typically framed from a knowledge-centred perspective and academic exercise rather than a practise-centred perspective. Knowledge gains, learning content, and skill acquisition are the goals and 
transfer and assessment of that transfer of knowledge via online tools counts as normative progress in education. However, with a shift towards practise-centred perspective, learning is then conceptualized as moving from novice to expert practises, and novices participate in apprenticeship situations while performing tasks and being scaffolded in the presence of experts in a learning community.

\begin{abstract}
Methodological challenges also exist. While automated online tools and digital video based-approaches are available to capture user keystrokes, mouse clicks, computer screens, and user and community activity, researchers face the challenge of selecting points of viewing (Goldman-Segall, 1999), and data reduction - making judicious choices about which data sets to select to view, and how to analyze and interpret a largely quantitative database of information with nuanced interpretations of social uses, learning, and end-user meaning.
\end{abstract}

\title{
Implications for Educational Practises
}

Because children can competently perform complex tasks outside of school with digital technologies, but may not display these skills on school-type tasks, it will be important for both research and practise to understand the nature of learning in out-of-school settings and how to build upon the practises of youth in digitally-mediated learning environments to support learning in multiple settings including school classrooms through teacher professional development.

\footnotetext{
An on-going tension remains with the everyday practises of digital kids and the culture of schooling and the expectation that computers should contribute to learning. Games, 
Internet research projects, and personally-relevant media projects, like successful projectbased learning experiences, take extended time periods that do not always fit well into the structure and timing of schools. When computers are engaged in the classroom, teachers may continue to view computers as workplace skill development tools, digital games as leisure activities or a motivational stick ("you can play games if you finish your work") or text chatting and blogging as distractions to learning, rather than opportunities to build new forms of literacy or opportunities for discourse. The differences and difficulties in fitting the Internet-based practises of youth into the norms, expectations, and constraints of classroom curricula, scheduling, and teaching are well documented (Schoefield, 2006).

While digital kids have appropriated technologies and established set of practises and competencies that may exceed the level of fluency with information technologies than their parents, caregivers, and educators, adults still play an important educational role in the lives of digital kids. For example, in using tools like blogs and wikis to publish their thoughts, opinions, and ideas to the World Wide Web, digital kids will need help from educators to understand the broader context of their activities, the public nature of posting personal information and thoughts, and the ramifications of writing opinions and experiences that can be read years later by potential employers, colleagues, and friends. Educators can shape how technology is viewed, ensuring responsible, safe, and ethical practises are followed in its use and in the online environments, continuing to support children in their cognitive, social and moral development, however, recognizing that adults have different cultural histories and relationships with digital technology. 
Digital kids clearly demonstrate 'repertoires of practise' and it is important to both study how practises developed in one setting migrate to other settings, as well as how to support the continuity of these practises across informal and formal settings. For example, the use of cell phones among teens is part of their everyday practises (e.g., exchanging text messages, playing games, verifying information) that are carried into formal settings, causing educators and schools to question and in some cases, ban their use in schools. Teachers and school administrators will bear the burden of re-establishing classroom norms, formulating new rules of engagement, and/or finding new ways to use cell phones for productive learning in schools. The boundaries of learning spaces and who has control over the technology will have to be revisited and renegotiated. In addition, the role of educators, parents, and caregivers becomes one of stewards of activity - helping to recognize, bridge, and link everyday thinking and activities of digital kids from school to home, and from every activity to classroom activities in a reciprocal "two way literacy." Another approach to linking practises across settings is to leverage the Internet and digital medium as a repository and evolving collection of learner ideas. Children can use networked digital media, digital libraries, and online web-based portfolios to create digital artifacts and persistent electronic representations that preserve individual and collaborative activity that can be revised, built upon, and reflected upon over time and accessible from home and school, serving as another way to build continuity of practises between informal and formal learning environments. Researchers have suggested that allowing students, especially at risk students, to personalize the medium in games would allow these learners to relate to the curriculum and to youth cultures (Mitchell \& Savill-Smith, 2004).

p. 27 
Focus of instruction should be not solely on the content, but about those collaborative practises and intellectual capacities digital kids can bring and be empowered to bring to a learning situation. Thus, recognizing that computers are not limited to being knowledge transmission and knowledge-centred tool, but often are an activity-centred tool for supporting children's deep and embedded practises with peers and educators in a horizontal participation structure with reciprocal roles (Rogoff, Matusov, \& White, 1996; Rogoff, 2003; Lave \& Wenger, 1991). Educators have to necessarily become informed facilitators of digital technologies to build upon existing activity structures and social relationships. For example, in the use of online games, the practise of making predictions in an online game, planning a strategy, and testing its outcome, and reflecting upon a next move mirrors the steps in inquiry-based science investigations. In online game play, teachers can serve as facilitators in the process of making strategies explicit, stimulating reflection, group discussion, and writing skills.

With Internet based computers and devices, the geographies of childhood are changing. Youth are spending more time at home in front of computers, narrowing their physical geography, yet being able to reach out to anyone anywhere in the world (Facer, Furlong, Furlong, \& Sutherland, 2003). Social proximity via the computer becomes more meaningful for children than physical proximity for learning and socializing. From a practise standpoint, educators have the responsibilities of ensuring ethical uses of technology and fostering learners to take a responsible role in their use to avoid hacking, flaming, online theft, plagiarism, online bullying, and injuries to others. Adults also have the responsibility to promote and encourage outdoor physical activity. Monitoring and 
safety also includes knowing who else is online and monitoring the online social groups and relationships that children participate.

Another implication for practise is promoting gender equity in participation when implementing digital-based learning environments among youth. Researchers have found that the physical space around computers requires monitoring and turn-taking to ensure girls and boys get equal time and access (Ching, Kafai, \& Marshall, 2000.) Similarly, in homes, studies have shown that having a computer at home does not necessarily mean having access to one and that the computers should be treated as a resource involving time and space which has to be negotiated amongst all family members (Holloway \& Valentine, 2003).

\section{Ethical Considerations of Research with Minors}

Research in online contexts or in learning contexts that crosses institutional boundaries (e.g., mobile cell phone use, Internet accounts, cyber assessments) that govern different norms for the protection of human subjects will need to be addressed. Digital kids are posting information in online blogs that schools, courts of law, and other institutions are using as evidence. One issue that will need attention is working through issues with institutional review boards for human subjects for minors. For example, research that falls outside of school time in which children's online behaviours and activities are captured, or youth are asked to be self-documenting their activities by writing in online diaries and photographing their parents, siblings, and home life poses new challenges. Children become informants not only of their own activity and educational practise, but as informants of others and other aspects of family life creating issues of risk, ethics, and 
privacy. Some promising examples of camera-based multimedia studies and playing in public spaces that have passed institutional review boards do exist which is promising (cf. Philip Bell at Univ. of Washington, Coe Leta Stafford at IDEO, personal communication).

\section{Summary}

Studies about out-of-school informal learning experiences and interest-driven activities are sparse in comparison to studies of design and use of technology for schooling and legitimate educational activities. While different disciplinary traditions offer a range of methods to the study of digital kids, only a few science education researchers are taking this opportunity to leverage what is already known about learning, inquiry, collaboration, personal relevance, and social supports in schools to examine and design out-of-school settings. At this moment, there is a pluralistic approach to studying digital fluency that may benefit from coordinating and comparing observations and analyses. Drawing from a repertoire of approaches that include design-based research strategies offers a beginning to the study of digital kids' emergent practises given that most environments and tools being used by digital kids were not purposefully designed for education or learning research. To get a comprehensive picture, research will need to study learning across both school and out-of-school settings and activity spaces for work and recreation, and how practises from one setting are reified and adopted in another.

Digital kids have multiple opportunities to take a more active role in defining and choosing what activities they engage in, when they do so, and with whom in everyday settings. The boundaries of learning and play are formed by learning events in online 
spaces created by digital kids and their social norm, practises, beliefs which typically are intergenerational, culturally inclusive, fluid in arrangements, and collaborative. Research will need to view ICTs, mobile phones, Internet, games, not only as a resource for learning, but also a context for studying activity and practises of digital kids. Adults' views on what counts as learning and legitimate learning activities will need to be reconceived and renegotiated in light of the practises of children as we learn how digital kids develop interests, knowledge, and expertise in non-academic domains. As more studies are conducted and aggregated across activity spaces of digital kids, a researchinformed view of the influences of digital technologies on learning and the contributions of digitally-mediated environments in everyday activity can be better assessed and conceptualized as valuable learning activity.

\section{Acknowledgments}

This work was supported in part by a grant to the author from MacArthur Foundation to synthesize research on digital learning and play. This work also benefited from a roundtable discussion on the topic of informal learning and digital kids with many key people who attended the 2005 Bay Area Institute, an event of the Center for Informal Learning and Schools funded by the U.S. National Science Foundation. The ideas in this paper do not necessarily reflect the views of these foundations.

\section{References}

Art Center College of Design (2004). Tweens: Technology, Agency, and Engagement A Model for Design Research. Media Design Program Publication.

\section{p. 31}


Barab, S., Warren, S. \& Ingram-Goble, A. (2006). Academic Play Spaces: Designing Games for Education. Paper presented at the American Educational Research Association, San Francisco. March 14, 2006. Retrieved on November 5, 2006 from http://inkido.indiana.edu/research/onlinemanu/papers/acad_play.pdf

Barron, B. (2004). Learning Ecologies for Technological Fluency: Gender and Experience Differences. Journal Educational Computing Research, 31(1), 1-36.

BBC Online. Cyber bullies haunt young online. Tuesday, 14 March 2006. Retrieved on March 14, 2006 from http://news.bbc.co.uk/1/hi/technology/4805760.stm

Bell, P. (2004) On the theoretical breadth of design-based research in education, Educational Psychologist, 39(4), 243-253

Bell, P., Bricker, L. A., Lee, T. R., Reeve, S., Zimmerman, H. T. (2006). Understanding the cultural foundations of children's biological knowledge: Insights from everyday cognition research. . In Barab, S., Hay, K. E., and Hickey, D. T. (Eds) $7^{\text {th }}$ International Conference of the Learning Sciences, ICLS 2006, Vol 2., 1029-1035.

Bers, M. (2001) Identity construction environments: Developing personal and moral values through the design of a virtual city. The Journal of the Learning Sciences, 10(4), 365-415. NJ: Lawrence Erlbaum Associates, Inc.

Brown, J. S. (2000). Growing up digital. Change, March/April, pp. 11-20.

Callanan, M. \& Oakes, L. A. (1992). Preschoolers' questions and parents' explanations: Causal thinking in everyday activity. Cognitive Development, 7, 213-233.

Ching, C. C., Kafai, Y. B., \& Marshall, S. (2000). Spaces for change: Gender and technology access in collaborative software design. Journal of Science Education and Technology, 9(1), 67-78.

p. 32

URL: http://mc.manuscriptcentral.com/tsed Email: editor_ijse@hotmail.co.uk 
Cheskin Research. (2002). Designing Digital Experiences for Youth. October. www.cheskin.com/cms/files/i/articles//19_CheskinYouthPOVII.pdf

Children's Partnership (2005) Measuring digital opportunity for America's children: Where we stand and where we go from here. By Wendy Lazarus and Andrew Wainer with Laurie Lipper, June. Retrieved November 06, 2006 from: http://www.contentbank.org/AM/Template.cfm?Section=Research_From_The_Chil drens_Partnership\&Template=/CM/ContentDisplay.cfm $\&$ ContentFileID=1089

CILS: Center for Informal Learning and Schools (www.exploratorium.edu/cils)

Corsaro, W. A. (2003) “We're friends, right?” Sharing and social participation in Kid's Culture. In Corsaro, W. (Ed.) Inside Kid's Culture. Joseph Henry Press, 36-65.

Crabtree, J., Nathan, M., \& Roberts, S. (2003). MobileUK: Mobile phones and everyday life London: The Work Foundation.

Dede, C. (2005). Planning for neomillennial learning styles. EDUCAUSE Quarterly, 28(1), 7-13. Retrieved September 23, 2005 from http://www.educause.edu/pub/eq/eqm05/eqm0511.asp?bhcp=1

Design-Based Research Collective. (2003). Design-based research: An emerging paradigm for educational inquiry. Educational Researcher, 32(1), 5-8.

DiSessa, A. (2000). Changing minds: Computers, learning, and literacy. MIT Press Dix, A. (2003). Being Playful - learning from children. In Proc. IDC 2003, ACM Press (2003), pp. 3-9

Donath, J. \& Boyd, D. (2004). Public displays of connection. BT Technology Journal, 22(4), 71-82, October.

Druin, A. (2002). The role of children in the design of new technology. Behavior and Information Technology, 21(1),1-25

p. 33 
Egan, J. (2000, December 10). Lone gay teen seeking same: How Jeffrey found friendship, sex, heartache / and himself / online. New York Times Magazine. $\begin{array}{lllll}\text { Accessed online } & 2003 \text { on } & \text { from }\end{array}$ http://www.nytimes.com/library/magazine/home/20001210mag-online.html Engeström, Y. (1996). Perspectives on activity theory. Cambridge: Cambridge University Press.

Facer, K., Furlong, J., Furlong, R. \& Sutherland, R. (2003). ScreenPlay: Children and Computing in the Home. Routledge Falmer, London.

Foley, B. J. \& Kobaissi, A. (2006). Using virtual chat to study in informal learning in online environments. Paper presented at the Annual Meeting of the American Educational Researcher Association, AERA 2006.

Future Lab (2004). Report 7: Literature Review in Informal Learning with Technology Outside School. Julian Sefton-Green, WAC Performing Arts and Media College $\begin{array}{llll}\text { Retrieved } & \text { November } & 5, & 2006\end{array}$ http://www.futurelab.org.uk/research/reviews/07_01.htm

Gee, J. (2003). What video games have to teach us about learning and literacy. New York: Palgrave MacMillan.

Geertz, C. (1972). Deep play: Notes on the Balinese cockfight. In: Clifford Geertz (Ed.), Myth, Symbol and Culture, 1-37. New York: W.W. Norton \& Company, Inc.

Green, N. (2002). On the move: Technology, mobility, and the mediation of social time and space. The information society, 18, 281-292.

Goldman-Segall (1999). Minding machines. From Points of viewing: A Digital Ethnographers Journey. Cambridge: MIT Press

p. 34 
Goldstein, J. H. (1994) Sex differences in toy preference and video game play. In J. Goldstein (Ed.). Toys, play, and child development. (pp. 110-129). New York: Cambridge University Press.

Guttierez, K. D. (2002) Studying Cultural Practises in Urban Learning Communities. Human Development, 45:312-321

Holloway, S. L. \& Valentine, G. (Eds.). (2000). Children's geographies: Playing, living, learning (pp. 139-155). London and New York: Routledge.

Hutchinson, H., Mackay, W., Westerlund, B., Bederson, B. B., Druin, A., Plaisant, C., Beaudouin-Lafron, B. Conversy, S., Evans, H., Hansend, H, \& Sundblad, Y. (2003) Technology Probes: inspiring design for and with families. Proceedings of the SIGCHI conference on Human factors in computing systems. Ft. Lauderdale, Florida, USA: pp. 17 - 24

Hutt, C. (1979) Exploration and Play. In B. Sutton-Smith, eds. Play and Learning. New York: Gardner, pp. 175-194

Hyder, T. (2004) Chapter 1: Children and Development: The Importance of Play. In War, Conflict and Play. Open University Press. pp. 1-23

Ito, M. (2004). Personal portable pedestrian: Lessons from Japanese mobile phone use. Paper presented at the Mobile Communication and Social Change: The 2004 International Conference on Mobile Communication, Seoul, Korea.

Ito, M. (2005) Technologies of the Childhood Imagination: Yugioh, Media Mixes, and Everyday Cultural Production To appear in Joe Karaganis and Natalie Jeremijenko Ed., Structures of Participation in Digital Culture. Duke University Press. Retrieved from http://www.itofisher.com/mito/archives/technoimagination.pdf 
Jordan, B., \& Henderson, A. (1995). Interaction analysis: Foundations and practise. The Journal of the Learning Sciences, 4(1), 39-103.

Johnson, S. (2005) Everything Bad is Good for You: How Today's Popular Culture is Actually Making us Smarter. Riverhead Books, New York.

Kaiser Family Foundation (2005). The Effects of Electronic Media on Children Ages Zero to Six: A History of Research -- Issue Brief. Retrieved on November 5, 2006 from http://www.kff.org/entmedia/7239.cfm

Kaiser Family Foundation. (1999) Kids and Media @ the New Millennium: A comprehensive National Analysis of children's media use (Menlo Park, CA: Kaiser Family Foundation, 1999). Retrieved on November 5, 2006 from http://www.kff.org/entmedia/1535-index.cfm

Kasesniemi, E., \& Rautiainen, P. (2002). Mobile culture of children and teenagers in Finland. In J. E. Katz \& M. Aakhus (Eds.), Perpetual contact: Mobile communication, private talk, public performance (pp. 170-192). Cambridge, UK: Cambridge University Press.

Keith, S. \& Martin, M. E. (2005). Cyber-Bullying: Creating a Culture of Respect in a Cyber World. Reclaiming Children and Youth: The Journal of Strength-based Interventions, 13(4) p. 224 Winter 2005

Kindberg, T., Spasojevic, M., Fleck, R., \& Sellen, A. (2004). How and why people use camera phones. HP Labs Bristol. Technical Report \#HPL-2004-216. Retrieved on March 22, 2006 from www.hpl.hp.com/techreports/2004/HPL-2004-216.pdf

Kyratzis, A. (2004). Talk and Interaction among Children and the Co-construction of Peer groups and Peer Culture. Annual Review of Anthropology, 33:625-49.

p. 36 URL: http://mc.manuscriptcentral.com/tsed Email: editor_ijse@hotmail.co.uk 
Lamberty, K.K. \& Kolodner, J.L. (2005). Camera Talk: Making the Camera a Partial Participant. Proceedings of the SIGCHI conference on Human factors in computing systems (CHI 2005) Portland, Oregon, April 2-7. (pp. 839-848). New York, NY: ACM Press.

Lave, J. \& Wenger, E. (1991). Situated Learning: Legitimate Peripheral Participation. Cambridge University Press.

Lenhart, A. \& Madden, M. (2005). Teen Content Creators and Consumers. Pew Internet and American Life Project. November.

Lenhart, A, Madden, M., \& Hitlin, P. (2005). Teens and Technology: Youth are Leading the Transition to a Fully Wired and Mobile Nation. Pew Internet and American Life Project, July 2005

Lenhart, A., Rainie, L., \& Lewis, O. (2001). Teenage life online: The rise of the instant message generation and the Internet's impact on friendships and family relationships. Washington, D.C.: Pew Internet \& American Life Project.

Livingstone, S. B., \& Magdalena (2004). UK Children Go Online: Surveying the experiences of young people and their parents, Economic and Social Research Council: E-Society Programme.

Loh, B., Radinsky, J., Reiser, B.J., Gomez, L.G., \& Edelson, D.C. (1997). The Progress Portfolio: Promoting reflective Inquiry in complex investigation environments. In the Proceedings of Computer Supported Collaborative Learning: CSCL 97. Toronto, Canada.

Lyman, P. with Alison Billings, Sarah Ellinger, Megan Finn and Dan Perkel (2005). Literature Review Kids' Informal Learning and Digital-Mediated Experiences. 
White paper for the MacArthur Foundation. Retrieved on November 5, 2006 from http://www.exploratorium.edu/research/digitalkids/Lyman_DigitalKids.pdf

Maldonado, H., Lee, B., \& Klemmer, S. (2006). Technology for Design Education: A Case Study. Conference on Computer Human Interaction: CHI 2006, April 22-27. Montreal, Canada. ACM 1-59593-298-4/06/0004.

Martin, L. (2004). An Emerging Research Framework for Studying Informal Learning and Schools. Science Education. Vol. 88, Supplement 1. S71-82

Mitchell A. \& Savill-Smith C. (2004). The use of computer and video games for learning. A Review of the Literature. London: Learning and Skills Development Agency. Retrieved on November 5, 2006 from http://www.lsda.org.uk/files/PDF/1529.pdf

Murray, N. D. (1997). Welcome to the Future: The Millennial Generation. Journal of Career Planning and Employment. 57(3) p. 36-40

National Academy of Sciences (2005). National Academy Board on Science Education: Workshop on ICT Fluency and High School graduation outcomes. October 23-24, 2005, Washington, DC. Retrieved on November 5, 2006 from http://www7.nationalacademies.org/bose/ICT_Fluency_Workshop_Draft_Agenda_ October_23_20005.html

Nespor, J. (1997). Intersections of Kids, Signs, and Popular Culture. In Nespor, J. Tangled Up in School: Politics, Space, Bodies, and Signs in the Educational Process. Lawrence Erlbaum Associates, Mahwah, NJ. pp. 162-192

National Research Council Committee on Information Technology Literacy. (1999). Being fluent with information technology. Washington, D.C.: National Academy Press.

p. 38 
NSF LIFE Center - the Learning in Formal and Informal Environments. http://lifeslc.org/

Oblinger, D. G. (2003). Boomers, Gen-Xers and millennials: Understanding the new students. Educause Review, July/August, 37-47. Retrieved April 21, 2005 from http://www.educause.edu/ir/library/pdf/erm0342.pdf

Owston, R., Kushniruk, A., Ho, F. Pitts, K., Wideman, H. (2005). Improving the Design of Web-based Games and Simulations through Usability Research. ED-MEDIA Annual Conference, Montreal, pp. 1162-1167, June.

Pea, R. (2006). Chapter 55: Video-as-data and Digital Video Manipulation Techniques for Transforming Learning Sciences Research, Education, and other Cultural Practises. In J. Weiss, J. Nolan, J. Hunsinger, and P. Trifonas (Eds.), The International Handbook of Virtual Learning Environments, Vol. 14, XXXV, pp. 1321-1393. Springer.

Prensky, M. (2006). Don't Bother Me Mom--I'm Learning! Paragon House Publishers.

Rogoff, B. (2003). The Cultural Nature of Human Development, New York: Oxford University Press.

Rogoff, B., Matusov, E., \& White, C. (1996). Models of Teaching and Learning: Participation in a Community of Learners. In D.R. Olson \& N. Torrance (Eds), The handbook of education and human development. Oxford, UK: Blackwell, pp. $388-414$

p. 39 URL: http://mc.manuscriptcentral.com/tsed Email: editor_ijse@hotmail.co.uk 
Schofield, J. (2006). Internet Use in Schools: Promise and Problems. In R. Keith Sawyer (Ed.), Cambridge Handbook of the Learning Sciences, Cambridge University Press, pp. $521-534$

Squire, K. \& Jenkins, H. (2004). Harnessing the power of games in education. Insights 3 (1), pp. 5-33.

Steinkuehler, C. \& Chmiel, M. (2006). Fostering scientific habits of mind in the context of online play. In Barab, S., Hay, K. E., and Hickey, D. T. (Eds) $7^{\text {th }}$ International Conference of the Learning Sciences, ICLS 2006, Vol 2. pp. 723-729

Stevens, R. \& Hall, R. (1997) Seeing Tornado: How Video Traces Mediate Visitor Understandings of (Natural?) Phenomena in a Science Museum, John Wiley and Sons.

Thornburgh, D., H.S. Lin (Eds.). (2002). Youth, pornography and the Internet. Washington, D.C., National Academy Press.

Thorton, P. \& Houser, C. (2004). Using mobile phones in education. In J. Roschelle, T.W. Chan, Kinshuk, \& S. Yang (Eds.), Proceedings of the $2^{\text {nd }}$ IEEE Wireless Mobile Technologies in Education Conference, WMTE 2004, pp. 3-10, New York: IEEE Press

Turkle, S. (1999). What are we thinking about when we are thinking about computers? In M. Biagioli (Ed.), The Science Studies Reader (pp. 543-552). New York and London: Routledge.

van Schie, E. G. M. \& Wiegman, O. (1997). Children and video games: Leisure activities, aggression, social integration, and school performance. Journal of Applied Social Psychology, 27, pp. 1175-1194.

p. 40 URL: http://mc.manuscriptcentral.com/tsed Email: editor_ijse@hotmail.co.uk 
VanDeventer, S. S. and White, J. A. (2002). Expert behavior in children's video game play. Simulation and Gaming. 33(1): 28-48.

Van Kesteren, U., Bekker, M., Vermeeren, A, \& Lloyd, P. (2003). Assessing usability evaluation methods on their effectiveness to elicit verbal comments from children subjects. In Proc. IDC 2003, ACM Press, pp. 41-49

Vavoula, G. (2005). A Study of Mobile Learning Practises, Internal Report, Deliverable 4.4 for the MOBIlearn project (IST-2001-37440)

Wenger, E. (1999). Communities of Practice: Learning, Meaning, and Identity. Cambridge University Press. 